\title{
Effects of Hypericum perforatum on turning behavior in an animal model of Parkinson's disease
}

\author{
Débora Dalla Vecchia1, Marissa Giovanna Schamne', Marcelo Machado Ferro², Ana Flávia Chaves \\ dos Santos ${ }^{1}$, Camila Lupepsa Latyki ${ }^{1}$, Danilo Vieira de Lara ${ }^{1}$, Juliana Ben ${ }^{3}$, Eduardo Luiz Moreira ${ }^{3}$, \\ Rui Daniel Prediger ${ }^{3}$, Edmar Miyoshi ${ }^{1, *}$
}
${ }^{1}$ Department of Pharmaceutical Sciences, State University of Ponta Grossa, Ponta Grossa, PR, Brazil, ${ }^{2}$ Department of General Biology, State University of Ponta Grossa, Ponta Grossa, PR, Brazil, ${ }^{3}$ Department of Pharmacology, Federal University of Santa Catarina, Florianópolis, SC, Brazil

\begin{abstract}
Parkinson's disease (PD) is an age-related neurodegenerative disorder characterized by the slow and progressive death of dopaminergic neurons in the (substantia nigra pars compact). Hypericum perforatum (H. perforatum) is a plant widely used as an antidepressant, that also presents antioxidant and anti-inflammatory properties. We evaluated the effects of $H$. perforatum on the turning behavior of rats submitted to a unilateral administration of 6-hydroxydopamine (6-OHDA) into the medial forebrain bundle as an animal model of PD. The animals were treated with $H$. perforatum $(100,200$, or $400 \mathrm{mg} / \mathrm{kg}$, v.o.) for 35 consecutive days (from the $28^{\text {th }}$ day before surgery to the $7^{\text {th }}$ day after). The turning behavior was evaluated at 7,14 and 21 days after the surgery, and the turnings were counted as contralateral or ipsilateral to the lesion side. All tested doses significantly reduced the number of contralateral turns in all days of evaluation, suggesting a neuroprotective effect. However, they were not able to prevent the 6-OHDA-induced decrease of tyrosine hydroxylase expression in the lesioned striatum. We propose that $H$. perforatum may counteract the overexpression of dopamine receptors on the lesioned striatum as a possible mechanism for this effect. The present findings provide new evidence that $H$. perforatum may represent a promising therapeutic tool for $\mathrm{PD}$.
\end{abstract}

Uniterms: Parkinson's disease/treatment/experimental study. H. perforatum/phytotherapy/neuroprotective effect. Turning behavior. 6-OHDA.

\begin{abstract}
A Doença de Parkinson é uma doença neurodegenerativa relacionada à idade, caracterizada pela morte lenta e progressiva de neurônios dopaminérgicos da substância negra pars compacta. O Hypericum perforatum (H. perforatum) é um fitoterápico utilizado como antidepressivo, apresentando propriedades antioxidantes, anti-inflamatórias e nootrópicas. Neste trabalho, avaliaram-se os efeitos do tratamento com $H$. perforatum no comportamento rotatório de ratos no modelo da doença de Parkinson induzido pela administração unilateral de 6-OHDA no feixe prosencefálico medial. Ratos Wistar machos foram tratados com H. perforatum $\left(100,200\right.$ ou $400 \mathrm{mg} / \mathrm{kg}$, v.o.) por 35 dias (do $28^{\circ}$ dia antes até o $7^{\circ}$ dia após a lesão). As rotações ipsilaterais e contralaterais à lesão foram registradas no $7^{\circ}, 14^{\circ}$ e $21^{\circ}$ dias após a cirurgia. As três doses de $H$. perforatum utilizadas reduziram o número de rotações contralaterais, indicando um possível efeito neuroprotetor da planta. Porém, o H. perforatum não impediu a redução na expressão da enzima tirosina hidroxilase no estriado lesionado, quantificada por Western blot. Propomos que o $H$. perforatum possa bloquear o aumento da expressão dos receptores dopaminérgicos no estriado lesionado com 6-OHDA. Entretanto, estudos adicionais são necessários para identificar o mecanismo exato pelo qual o $H$. perforatum reduziu o número de rotações contralaterais. Os resultados do presente estudo sugerem o $H$. perforatum como um potencial agente terapêutico para a doença de Parkinson.
\end{abstract}

Unitermos: Doença de Parkinson/tratamento/estudo experimental. H. perforatum/fitoterapia/efeito neuroprotetor. Comportamento rotatório. 6-OHDA.

\footnotetext{
*Correspondence: E. Miyoshi. Departamento de Ciências Farmacêuticas, Universidade Estadual de Ponta Grossa, 84030-900 - Ponta Grossa - PR, Brasil. E-mail: edmar@uepg.br
} 


\section{INTRODUCTION}

Parkinson's disease (PD) is a debilitating disease characterized by the progressive loss of dopaminergic neurons in the substantia nigra pars compacta (SNpc) (Hirsch et al., 1988, 2005). At the time of diagnosis, patients typically display variety of motor impairments, including bradykinesia, resting tremor, rigidity, and postural instability.

Although the etiology of the neurodegenerative process found in PD is not completely understood, it has been suggested that a state of oxidative imbalance is triggered by one or more factors, including brain aging, genetic predisposition, mitochondrial dysfunction, free radical production and environmental toxins (Henchcliffe, Beal, 2008; Zhou, Huang, Przedborski, 2008). Novel therapeutic strategies support the application of reactive oxygen species (ROS) scavengers, transition metal chelators, nonsteroidal anti-inflammatory drugs, natural antioxidant polyphenols, anti-apoptotic drugs, and bioenergetic drugs in monotherapy or as part of an antioxidant cocktail formulation (Mandel, Youdim, 2004).

The plant $H$. perforatum L. (Saint John's wort) possesses anti-inflammatory, antioxidant, and nootropic properties (Rodríguez-Landa, Contreras, 2003; Griffith et al., 2010). Here, we investigated its effects on the nigrostriatal pathway lesion induced by unilateral injection of 6-hydroxydopamine (6-OHDA) into rats' medial forebrain bundles, which led to partial retrograde degeneration of dopamine neurons in the substantia nigra. This model is widely used to investigate novel agents for relieving motor symptomsas well as potential neuroprotective compounds in PD (Blum et al., 2001).

\section{MATERIAL AND METHODS}

All procedures used in the present study were conducted according to national and international legislation, with approval of the Ethics Committee for Animal Research of the Universidade Estadual de Ponta Grossa (UEPG) (Process CEUA 14/2011/ Protocol UEPG-7821/2011). Subjects were adult male Wistar rats (3 months old, 280-340g) from the UEPG breeding stock. The animals were randomly divided into 8 groups $(\mathrm{N}=$ 6-12): SHAM-vehicle, SHAM-HP100, SHAM-HP200, SHAM-HP400, 6-OHDA-vehicle, 6-OHDA-HP100, 6-OHDA-HP200, and 6-OHDA-HP400.

Dry extract of aerial parts of $H$. perforatum $(0.3 \%$ hypericin) (kindly donated by Laboratório Herbarium Botânico S/A, Colombo, Paraná, Brazil) was suspended in distilled water and administered by gavage $(0,100$, 200 , or $400 \mathrm{mg} / \mathrm{kg} / 2 \mathrm{ml} / \mathrm{kg}$ body weight). The control group received distilled water in the same volume. This administration happened once a day for 35 consecutive days (from 28 days before surgery to 7 days post-surgery).

On the surgery day, rats were anesthetized with thiopental (50 mg/kg, i.p.) and lesioned with 6-OHDA (Sigma-Aldrich Inc., St. Louis, MO, USA) ( $8 \mu \mathrm{g}$ in $0.2 \%$ ascorbic acid $0.9 \%$ saline solution) on the left medial forebrain bundle following stereotaxic coordinates: anteroposteriorly $-1.9 \mathrm{~mm}$ from the bregma; mediolaterally $+1.9 \mathrm{~mm}$ from the midline; and dorsoventrally $-7.9 \mathrm{~mm}$ from the skull (Paxinos, Watson, 1998; Da Cunha et al., 2008).

The animals of the SHAM group received the vehicle solution $(0.2 \%$ ascorbic acid in $0.9 \%$ saline solution). On the $7^{\text {th }}, 14^{\text {th }}$, and $21^{\text {st }}$ days after surgery, animals' turning behavior was tested after administration of apomorphine (1mg/kg, s.c., Sigma-Aldrich). The number of $360^{\circ}$ turns toward the lesioned (ipsilateral) or opposite side (contralateral) was recorded for $1 \mathrm{~h}(\mathrm{Da}$ Cunha et al., 2008).

At the $22^{\text {nd }}$ day after surgery, the animals were decapitated, and their striata were collected and stored in a freezer at $-80^{\circ} \mathrm{C}$ until analysis. Dopaminergic neuron death was quantified by tyrosine hydroxylase (TH) Western blot (Moreira et al., 2010). TH expression was compared between lesioned and contralateral sides. All values are expressed as means \pm S.E.M. The statistical analysis was carried out using two-way analysis of variance (ANOVA). Following significant ANOVAs, post-hoc comparisons were performed using the Newman-Keuls test. The accepted level of significance for the tests was $P \leq 0.05$. All tests were performed using the Statistica ${ }^{\circledR}$ software package (StatSoft Inc., Tulsa, OK, USA).

\section{RESULTS AND DISCUSSION}

Figure 1 shows contralateral turns induced by apomorphine in hemiparkinsonian rats at 7 (Figure 1A), 14 (Figure 1B), and 21 (Figure 1C) days after surgery. Two-way ANOVA indicated a significant effect of the lesion, since the 6-OHDA vehicle was different from the SHAM vehicle at the $7^{\text {th }}[\mathrm{F}(1,55)=17.86, \mathrm{p}<0.001], 14^{\text {th }}$ $[\mathrm{F}(3,55)=32.26, \mathrm{p}<0.001]$, and $21^{\text {st }}$ days $[\mathrm{F}(3,55)=$ $26.47, \mathrm{p}<0.001]$. Regarding the H. perforatum treatment, all tested doses significantly reduced the number of turns induced by the 6-OHDA lesion on the $7^{\text {th }}[\mathrm{F}(3,55)=8.73$, $\mathrm{p}<0.001], 14^{\text {th }}[\mathrm{F}(1,55)=56.99, \mathrm{p}<0.001]$, and $21^{\text {st }}$ days $[\mathrm{F}(1,55)=45.41, \mathrm{p}<0.001]$. The interaction between the two factors was also similar for the $7^{\text {th }}[\mathrm{F}(3,55)=10.35$, 

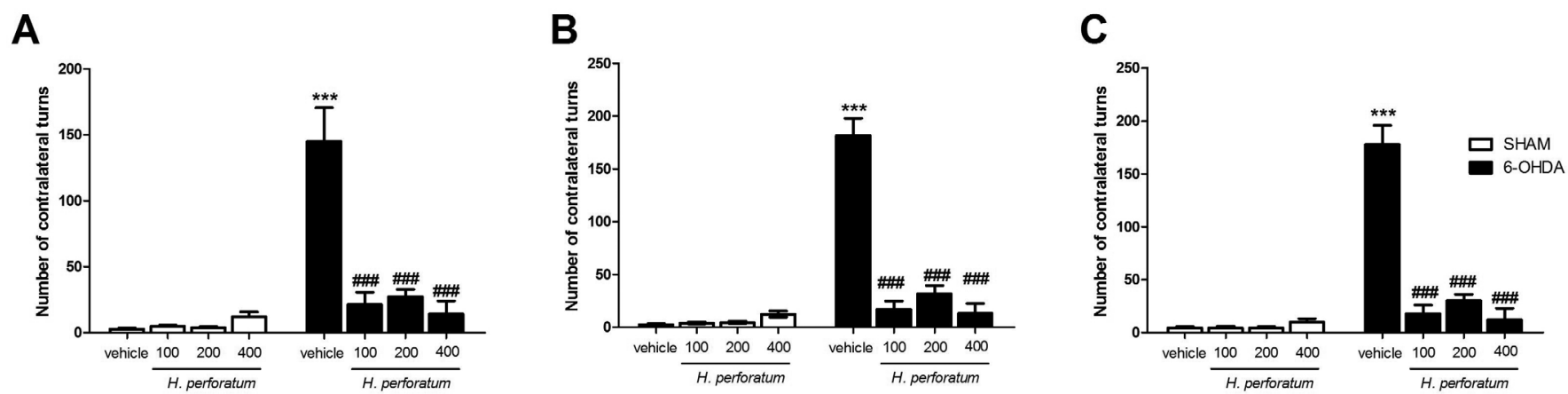

D

\section{Ipsilateral lesioned striata}

\section{$\mathbf{E}$}

\section{Contralateral lesioned striata}
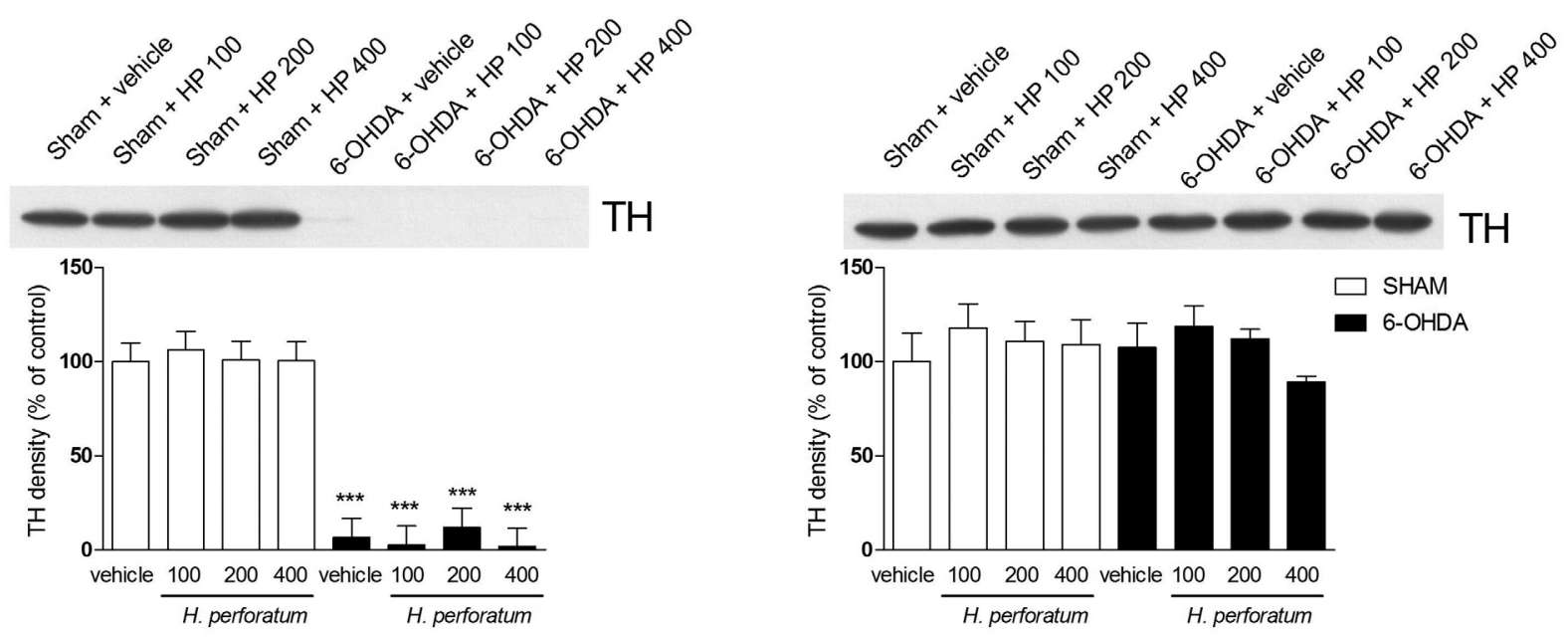

FIGURE 1 - Number of contralateral turns induced by apomorphine (1 mg/kg, s.c.) at 7 (A), 14 (B), and 21 (C) days after unilateral surgery with 6-OHDA in rats treated with different doses of extract of $H$. perforatum $(100,200$, or $400 \mathrm{mg} / \mathrm{kg})$ or vehicle for 35 days. Western blot of the TH expression in ipsilateral (D) and contralateral (E) to the lesion striata. $\mathrm{N}=6-12$ animals per group. ${ }^{* * *} \mathrm{P}<0.001$ compared to SHAM + Vehicle group, ${ }^{\# \#} \mathrm{P}<0.001$ compared with the 6-OHDA-vehicle (two-way ANOVA followed by NewmanKeuls post-hoc test).

$\mathrm{p}<0.001], 14^{\text {th }}[\mathrm{F}(3,55)=36.37, \mathrm{p}<0.001]$, and $21^{\text {st }}$ days $[\mathrm{F}(3,55)=28.67, \mathrm{p}<0.001]$.

The 6-OHDA-induced turning behavior observed in this work is in agreement with previous literature where severely unilaterally lesioned animals rotate toward the side contralateral to the lesion when challenged with apomorphine (a dopamine receptor agonist) (Figures $1 \mathrm{~A}, \mathrm{~B}$, and $\mathrm{C}$ ). This rotation behavior occurs due to the imbalance of dopaminergic neurotransmission between injured and uninjured sides, so a larger lesion results in more rotations. This imbalance is caused by the overexpression of dopamine receptors in lesioned striatum, thus potentiating the apomorphine effect $(\mathrm{Da}$ Cunha et al., 2008, 2009).

Animals of SHAM groups treated with $H$. perforatum did not perform contralateral turns when challenged with apomorphine, indicating that the $H$. perforatum extract, or its withdrawal, did not affect rotational behavior. The reduced number of contralateral turns of 6-OHDAlesioned animals treated with $H$. perforatum could indicate a reduced neuronal loss when compared to the 6-OHDA group treated with the vehicle, but this hypothesis was not supported by the Western blot results.

Studies have shown that the administration of 6-OHDA in laboratory animals' brains leads to dopaminergic neuronal death and consequent reduced expression of $\mathrm{TH}$ in the striatum and substantia nigra, producing motor impairments similar to those observed in patients in the advanced stages of PD (Yin, Cao, Xie, 2010). Corroborating with these results, 6-OHDA induced a significant reduction of striatal TH levels (Figure 1D) compared to the SHAMvehicle group $[\mathrm{F}(1,16)=186.42, \mathrm{p}<0.001]$. Surprisingly, 
although able to reduce the contralateral rotations induced by apomorphine, the three tested doses of $H$. perforatum were not able to prevent the reduction in TH expression in the striatum ipsilateral to the lesion $[\mathrm{F}(3,16)=0.10$, $\mathrm{p}=0.96]$. Moreover, we did not observe any statistical differences among groups in the TH expression on the striatum contralateral to the lesion (Figure 1E), indicating a selective degeneration of dopaminergic neurons in the hemisphere injected with 6-OHDA.

Other authors have demonstrated that $H$. perforatum can block dopamine reuptake by presynaptic neurons (Calapai et al., 2001; Menini, Gobbi, 2004). This mechanism could explain the reduced number of rotations seen on the $7^{\text {th }}$ day, but not on the $14^{\text {th }}$ and $21^{\text {st }}$ days after lesion, since the $H$. perforatum administration was only performed until the $7^{\text {th }}$ post-lesion day. Moreover, a direct agonistic effect of $H$. perforatum on dopamine receptors at later periods (i.e., 14 and 21 days) following its administration is also improbable.

One plausible hypothesis is that the H. perforatum may have hampered the overexpression of dopaminergic receptors on the lesioned side, which would have reduced the imbalance provoked by the 6-OHDA. Besides dopamine, $H$. perforatum also reduces serotonin and noradrenalin uptake, and it has been reported to have a brain-derived neurotrophic-factor-like effect (Leuner et al., 2007). Other authors indicate an interaction of hyperforin with non-dopaminergic receptors (Ikeda et al., 2012). Those effects in other structures, like the subthalamic nucleus, are involved on the modulation of turning behavior (Ikeda et al., 2012; Petri et al., 2013). Therefore, we propose that some of these mechanisms may have caused a long-term desensitization of the nigrostriatal synapses to the direct agonist apomorphine.

\section{CONCLUSION}

These results show for the first time that treatment with $H$. perforatum reduced the number of contralateral rotations in animals lesioned unilaterally with 6-OHDA and that these effects were not directly related with neuroprotective effects. These findings provide new evidence that $H$. perforatum may represent a promising therapeutic tool in $\mathrm{PD}$, thus being able to prevent motor symptoms of PD.

\section{ACKNOWLEDGEMENTS}

This work was supported by Conselho Nacional de Desenvolvimento Científico e Tecnológico (CNPq), Coordenação de Aperfeiçoamento de Pessoal de Nível
Superior (CAPES), and SETI/Fundação Araucária. RDP is supported by research fellowships from CNPq. The authors have no financial or personal conflicts of interest related to this work.

\section{REFERENCES}

BLUM, D.; TORCH, S.; LAMBENG, N.; NISSOU, M. F.; BENABID, A. L.; SADOUL, R.; VERNA, J. M. Molecular pathways involved in the neurotoxicity of 6-OHDA, dopamine and MPTP: contribution to the apoptotic theory in Parkinson's disease. Prog. Neurobiol., v.65, n.2, p.135172, 2001.

CALAPAI, G.; CRUPI, A.; FIRENZUOLI, F.; INFERRERA, G.; SQUADRITO, F.; PARISI, A.; DE SARRO, G.; CAPUTI, A. Serotonin, norepinephrine and dopamine involvement in the antidepressant action of Hypericum perforatum. Pharmacopsychiatry, v.34, n.2, p.45-49, 2001.

DA CUNHA, C.; WIETZIKOSKI, S.; FERRO, M.M.; MARTINEZ G. R.; VITAL, M. A. B. F.; HIPÓLIDE, D.; TUFIK, S.; CANTERAS, N. S. Hemiparkinsonian rats rotate toward the side with the weaker dopaminergic neurotransmission. Behav. Brain. Res., v.189, n.2, p.364372, 2008.

DA CUNHA, C.; WIETZIKOSKI E.C.; DOMBROWSKI, P.A.; BORTOLANZA, M.; SANTOS, L.M.; BOSCHEN, S.L.; MIYOSHI, E. Learning processing in the basal ganglia: a mosaic of broken mirrors. Behav. Brain. Res., v.199, n.1, p.157-170, 2009.

GRIFFITH, T. N.; VARELA-NALLAR, L.; DINAMARCA, M. C.; INESTROSA, N. C. Neurobiological effects of Hyperforin and its potential in Alzheimer's disease therapy. Curr. Med. Chem., v.17, n.5, p.391-406, 2010.

HENCHCLIFFE, C.; BEAL, M. F. Mitochondrial biology and oxidative stress in Parkinson disease pathogenesis. Nat. Clin. Pract. Neurol., v.4, n.11, p.600-6009, 2008.

HIRSCH, E.C.; HUNOT, S.; HARTMANN, A. Neuroinflammatory processes in Parkinson's disease. Parkinsonism. Relat. Disord., v.11, suppl.1, p.S9-S15, 2005.

HIRSCH, E.; GRAYBIEL, A.M.; AGID Y.A. Melanized dopaminergic neurons are differentially susceptible to degeneration in Parkinson's disease. Nature, v.334, n.6180, p.345-348, 1988. 
IKEDA, H.; KAMEI, J.; KOSHIKAWA, N.; COOLS, A. R. Nucleus accumbens and dopamine-mediated turning behavior of the rat: role of accumbal non-dopaminergic receptors. J. Pharmacol. Sci., v.120, n.3, p.152-164, 2012.

LEUNER, K.; KAZANSKI, V.; MULLER, M.; ESSIN, K.; HENKE, B.; GOLLASCH M. Hyperforin-a key constituent of St. John's wort specifically activates TRPC6 channels. FASEB J., v.21, n.14, p.4101-4111, 2007.

MANDEL, S.; YOUDIM, M.B. Catechin polyphenols: neurodegeneration and neuroprotection in neurodegenerative diseases. Free Radic. Biol. Med., v.37, n.3, p.304-317, 2004.

MENINI, T.; GOBBI, M. The antidepressant mechanism of Hypericum perforatum. Life Sci., v.75, n.9, p.1021-1027, 2004.

MOREIRA, E. L.; RIAL, D.; AGUIAR, A. S.; FIGUEIREDO, C. P.; SIQUEIRA, J. M.; DALBÓ, S.; HORST, H.; DE OLIVEIRA, J.; MANCINI, G.; DOS SANTOS, T. S.; VILLARINHO, J. G.; PINHEIRO, F. V.; MARINONETO, J.; DE BEM, A. F.; LATINI, A.; PIZZOLATTI, M. G.; RIBEIRO-DO-VALLE, R. M.; PREDIGER, R. D. Proanthocyanidin-rich fraction from Croton celtidifolius Baill confers neuroprotection in the intranasal 1-methyl-4phenyl-1,2,3,6-tetrahydropyridine rat model of Parkinson's disease. J. Neural. Transm., v.117, n.12, p.1337-1351, 2010.
PAXINOS, G.; WATSON, C. The rat brain in stereotaxic coordinates. 4.ed. San Diego: Academic Press, 1998.

PETRI, D.; PUM, M.; VESPER, J.; HUSTON, J. P.; SCHNITZLER A. GABAA-receptor activation in the subthalamic nucleus compensates behavioral asymmetries in the hemiparkinsonian rat. Behav. Brain. Res., v.252, n.252, p.58-67, 2013.

RODRÍGUEZ-LANDA, J. F.; CONTRERAS, C. M. A review of clinical and experimental observations about antidepressant actions and effects produced by Hypericum perforatum Extracts. Phytomedicine, v.10, n.8, p.688-699, 2003.

YIN, L. L.; CAO, Y.; XIE, K. Q. Decreased RGS9 protein level in the striatum of rodents undergoing MPTP or 6-OHDA neurotoxicity. Neurosci. Lett., v.479, n.3, p.231-235, 2010.

ZHOU, C.; HUANG, Y.; PRZEDBORSKI, S. Oxidative stress in Parkinson's disease: a mechanism of pathogenic and therapeutic significance. Ann. N. Y. Acad. Sci., v.1147, p.93-104, 2008.

Received for publication on $1^{\text {st }}$ August 2013 Accepted for publication on $21^{\text {st }}$ November 2013 
